\title{
Exploring the Gap Analysis of Generic Competences of Pre-Service Teachers in Pakistan
}

\author{
Mehlah Jabeen ${ }^{1}$, Muhammad Sarwar ${ }^{2}$, Ashfaque Ahmad Shah ${ }^{3}$
}

\begin{abstract}
Gap in desired and achieved generic competences among university students has always been a point of concern for educationists and researchers. Those who desire for higher level of competence have greater probability of ending up with higher level of achievement. The present study aims to analyse the gap in generic competences among the prospective teachers enrolled in a B.Ed-4 year programme. Prospective teachers' competence is one of the basic elements ensuring their student success in academic as well as professional life. This study investigated three gaps i.e. desire-gap (gap between desired and optimal level of prospective teachers regarding generic competences), achievement-gap (gap between achievement and optimal level of prospective teachers regarding generic competences) and desire-achievement gap (gap between desired and achievement level of prospective teachers regarding generic competences). There were only 13 public universities in Punjab offering B.Ed-4 year programme. Researchers conveniently sampled 210 prospective teachers from seven universities $(53 \%)$ in Punjab; and surveyed them through quantitative research method. An adopted competence scale (from an international project i.e. the Reflex Project) comprising 19 generic competences was used to collect the data. The analysis of the data revealed that all three gaps existed among the prospective teachers regarding their generic competences. Desired level (i.e. 80\%), though, high enough, nevertheless, yielded the desire-gap (100-80\%) of 20\%, which showed room for further development. Surprisingly, the achievement-gap (100-67\%) was found to be $33 \%$; and the desire-achievement gap (80-67\%) to be $16 \%$. Positive correlation showed (higher) achievement level associated with (higher) desired level. Positive relationship between desire and achievement levels implies that high desire brings high achievement. And to reach optimal level it is necessary
\end{abstract}

\footnotetext{
${ }^{1}$ PhD Scholar, Department of Education, University of Sargodha Email:mehlah.n.96@gmail.com

${ }^{2}$ Professor, Department of Education, University of Sargodha Email: drsarwar@ymail.com

${ }^{3}$ Assistant Professor, Department of Education, University of Sargodha Email:multanxa@gmail.com
} 
for the desire level to exalt it to the optimal point. The findings of the study may help prospective teachers to enhance their professional knowledge, skills and competences which increase their employment opportunity.

Keywords: Desire-Gap, Achievement-Gap, Desire-Achievement Gap, Prospective Teachers, Generic Competences

\section{Introduction}

Education plays a vital role in the societal and economic development of human beings by providing civilized and skilled workforce (Richta, 2018). Education will only achieve its goal when it produces graduates with competences that industry demands. The quality of education (specifically higher education) improves a country's ability to supply highly qualified and competent workforce to the job market. The job market demands both specific and generic competences from the prospective employees. Competence-based education, specifically, is expected to provide a gradual change from education to professional life (Fastré et al., 2013). In competence-based education (Shah, Sarwar, \& Shah, 2017) the objectives of education and the curriculum are determined using competences as a foundation (Kamphorst et al., 2013).

Higher education is expected to inculcate three kinds of competences; specific competence, generic competence and disposition competence among graduates (Chan et al., 2013; Shah, 2009). Consequently, higher education institutions are, continuously struggling to create competences in students to increase their employment opportunities, which are actually an increase in the human capital of an organization. But, students with professional degrees do not meet employers' desire in the workplace (Parvaiz, 2014). The employers expect from students to perform various competences at a number of levels in their professional life. It is really unfortunate that the students having professional degrees do not meet the expectations of the employers (Low, Bots, De La Rue \& Allen, 2016). Gap in desired and achievement among university students in their generic competences can never be overemphasised (Bui \& Porter, 2010; Hakim \& Bizri, 2015; Junior, 2014; Low, Botes, De La Rue, \& Allen, 2016; Metilda \& Neena, 2016). The gap in inculcating the required competences in the students as per desires of employers is a challenge for higher education institutions over the globe. There is a growing expectation from universities that the labour force be equipped with knowledge and competences needed to meet the demand of the labour market.

Parallel with the lifelong learning, higher education institutions are also focusing on competence based learning, especially in the generic competences in order to produce quality teachers (Gibbons, 1994; Gillies \& Howard, 2003). 
Therefore, the importance of a teacher training institute has never been overlooked. The Higher Education Commission (HEC) of Pakistan, in its commitment and continuous endeavour, has introduced the four years Bachelor of Education (B.Ed 4-year) programme to replace one year Bachelor of Education to improve the quality of teacher education (Mahmood, 2017). The 4year programme intends to inculcate high-level competences among students. The programme accepts 12 years of schooling as admission requirements. B.Ed 4-year program is expected to adequately prepare teachers for the profession in order to meet the expectations of the Department/Ministry of Education. The aim of the present study was to explore what the gaps are between desiredachievement levels of prospective teachers enrolled in B.Ed 4-year programme regarding generic competences.

\subsection{Objectives of the Study}

The main objectives of the study are to:

1. Analyse the gap between optimal level and desire level of generic competences of prospective teachers (desire-gap)

2. Analyse the gap between optimal level and achievement level of generic competences of prospective teachers (achievement-gap)

3. Analyse the gap between desire level and achievement level of generic competences of prospective teachers (desire-achievement gap)

\subsection{Significance of the Study}

The current study will shed light on the importance of generic competence development among teacher educators and prospective teachers of B.Ed 4-year programme. Additionally, the findings will glean for new insights into prospective teachers' desires and achievement levels of certain competences. The findings of the study may help prospective teachers to enhance their professional knowledge, skills and competences that help them for successful professional life and increase their employment opportunity. It may help teacher educators to improve their teaching strategies to inculcate generic competences among prospective teachers in producing quality teachers.

\subsection{Delimitations of the Study}

This study is delimited to only final year prospective teachers of B.Ed (Hons.) programme as they were studying in $7^{\text {th }}$ and $8^{\text {th }}$ semester.

\section{Literature Review}

The term competence has been widely used since the mid of the $20^{\text {th }}$ century. The similar terminologies, such as ability, capacity, capability and aptitude all reflect the complication and versatility of the notion (Kwan, 2016; Longweni \& Kroon, 2016; Mulder, 2007; Teixeira, Teixeira, Cardoso, Rosa, \& 
Magalhães, 2016). Rowe (1995) stated that the term competence can be used to mean a skill and the standard of performance acquired, on other side, competency is referred to the behaviour through which a specific performance is achieved. In fact, the first one deals with what people can do and second refers to how they do it. Rowe narrates that two different meanings are derived from the plurals of each term as competences (plural of competence) and competencies (plural of competency) are not the same. Competences are blend of skills performed satisfactorily, while, competencies are denoted to the behaviours adopted in the competent performance. It aims to stimulate knowledge, abilities, behaviours and values (Howells, 2018; Serna, Vega, García, \& Ruiz, 2018). Thus competence can be viewed as a blend of knowledge, ability, attitude and behavior in a person to perform a particular task. It may be known as a proficiency in skill to perform a job well (Siddoo, Sawattawee, Janchai, \& Yodmongkol, 2017b).

Commonly, there are two types of competences specific competences discipline-specific or job-specific and generic competences (Shah, 2009; Sidhu \& Pascual, 2010). Generic competences are the cognitive, social and behavioural traits that polish the professional attitude. These competences are also called fundamental competences, professional competences, soft skills, analytical competences and employability competences (Tuononen, 2019). The term generic competences are known in the literature for successful employment. The said term also used interchangeably with attributes, values, abilities and qualities. Additionally, the word generic advocates that such competences are not context bound, independent of the context of learning. Multiple professional competences have been recognized in the literature. The most commonly used competences are the problem solving, analytical thinking, teamwork, collaboration, interpersonal, and digital literacy (De La Harpe, Radloff, \& Wyber, 2000). According to Male (2010) the term generic competences include the abilities which are used to perform a variety of jobs and contexts. Employers working in international markets are looking forward for workforce that equipped enough with ability to perform beyond the context with multiple abilities or generic competences. These competences may not require in professional life, but they add to the candidate's human capital and their development in the career. The notion of globalization, the rapid change in technology and the appearance of new economies have increased the level of demand for a worker. The working of employers at global level market desires labour, with multidimensional and widespread generic competences. Therefore, the workplace is needed to perform according to the employer's desire or demand (Cunha et al., 2019; Rodríguez, Corona, \& Espinosa, 2019). To develop the competences in students as per desires of employers the education system of any nation can play 
a vital role. The employers believe that the universities should prepare students to become competent persons of the workforce. The graduates of the university are future professionals. Universities are responsible to inculcate employability competences in their graduates (Bui \& Porter, 2010). Higher education is moving toward focusing on competence-based learning (De La Harpe et al., 2000). However, the graduates are not performing in their professional life as per desire of employers.

The gap between desire of employers from newly recruited graduates' generic competences and actual level of competences that graduates present in the field has massively studied and reported in the literature by numerous researchers. Subramonian (2008) assessed the gap between the competences learnt by graduates during their studies and competences which they possess in the industry. He found a slight gap between competences achieved by hospitality students of Malaysia and competences which they perform in the workplace. Bui and Porter (2010) examined desire-achievement gap - that there is gap between the competences which the workplace expect from the students and the competences achieved by the students in New Zealand. They further explained that employers continue to find accounting graduates who are not ready to work. Because there is mismatch in the competences they have achieved and competences desired by the employers. The graduates need to develop more competences as per demand of job market. Naidoo, Jackling, Oliver, and Prokofieva (2011) analyzed the curriculum of Australian accounting graduates to examine employability competences for their successful professional life. The results showed that two types of competences gaps exist as perceived by the employers and academics - teamwork competences and verbal communication competences. A reasonable gap was found by Junior (2014) between the readers and the reporters. Similarly, Parvaiz (2014) examined the desire-achievement gap among students of accounting education regarding developing generic competences in Pakistan. Hakim and Bizri (2015) investigated in a study that there was gap between desire of employers regarding graduates and actual competences performed by them. In addition, employers reported that new accounting students lacked decision making skills. The aforementioned gaps signified the fact that there was less mutual interaction between employers and the teachers.

Metilda and Neena (2016) analyzed desire-achievement gap regarding generic competences in the perception of Indian business graduates. Higher gap was found in desire-achievement employability competences of Business graduates. Siddoo et al. (2017) examined the gap between employers' desire and competences of IT internship graduates that they demonstrate in the market. The 
results of the study depicted that employers have high desire from the students regarding competences in the field of technology but the students do not fulfil their expectations in that area. Shah, Sarwar, \& Shah (2017) conducted a study to explore generic competences among prospective teachers at Higher Education level in Pakistan. The prospective teachers could not achieve the competences at higher level. The higher education authorities should take tangible steps to remove the identified gap (Young \& Chapman, 2010).

\subsection{Research Design}

\section{Research Methodology}

The purpose of the study was to analyse the gap in generic competences among the prospective teachers enrolled in B.Ed-4 year programme. Research design of the study was descriptive in nature employing cross-sectional survey. This technique was considered appropriate due to relatively faster and inexpensive access to wider range of respondents.

\subsection{Population of the Study}

The prospective teachers enrolled in B.Ed-4 year programme of public sector universities of Punjab constituted the population for present study. There were only 13 public universities in Punjab offering B.Ed-4 year programme. Total number of population was about 650 prospective teachers (Source: prospectus of public sector universities of Punjab).

\subsection{Sample and Sampling Technique}

The researchers selected seven (07) universities through convenient sampling from northern, central and southern parts of Punjab, covering the whole geographical spread of the province. Purposively the selection criteria were the B.Ed-4 year programme. The researchers succeeded in collecting data through convenient sampling from more than $30 \%$ of the (650) participants. Researchers also recorded the perceptions of 35 teacher educators.

\subsection{Instrumentation}

For this study, competence scale was adopted. The scale comprising 19 generic competences had actually been developed for the Reflex Project, which was an international project implemented in 14 European countries and Japan. The scale was also used by Shah (2009) in France and after that it was validated by Shamim-ur-Rasul (2012) at higher education level in Pakistan. The sevenpoint rating scale (very low i.e. 1 to very high i.e. 7) was used to collect the perception of prospective teachers regarding their desire and achievement level of generic competences. Cronbach's Alpha value was 0.84, showing high reliability of the research instrument. Semi-structured interview schedule was 
also used to explore the perceptions of teacher educators regarding desireachievement gap of generic competences among prospective teachers.

\subsection{Data Collection}

The researchers personally visited the selected universities for data collection from the respondents. Before administering the competence scale to the respondents the researchers briefly explained the purpose of the study and introduced the important components of the research tools to develop positive rapport with the respondents.

\section{Data Analysis and Interpretation}

For data analysis, descriptive statistics that includes mean, percentages and Pearson correlation $(r)$ were employed for drawing the inferences.

Table 4.1

Desire-gap of Generic Competences

\begin{tabular}{|c|c|c|}
\hline Competences & Perceived Desire Level & Gap \\
\hline 1. Mastery of one's own discipline & 84.00 & 16.00 \\
\hline 2. Knowledge of other disciplines & 77.00 & 23.00 \\
\hline 3. Think analytically & 79.14 & 20.86 \\
\hline 4. Rapidly acquiring new knowledge & 80.29 & 19.71 \\
\hline 5. Effective negotiation & 75.00 & 25.00 \\
\hline 6. Performing well under pressure & 78.14 & 21.86 \\
\hline 7. Preparedness to novel opportunities & 80.43 & 19.57 \\
\hline 8. Co-ordinate with others & 77.86 & 22.14 \\
\hline 9. Efficient use of time & 81.00 & 19.00 \\
\hline 10. Work productively with others & 79.43 & 20.57 \\
\hline 11. Mobilizing abilities of others & 78.29 & 21.71 \\
\hline 12. Making your meanings clear to others & 81.29 & 18.71 \\
\hline 13. Asserting your authority & 79.14 & 20.86 \\
\hline 14. Using computers and the internet & 82.43 & 17.57 \\
\hline $\begin{array}{l}\text { 15. Coming up with the innovative ideas } \\
\text { and solutions }\end{array}$ & 81.14 & 18.86 \\
\hline $\begin{array}{l}\text { 16. Preparedness to question your and } \\
\text { others' ideas }\end{array}$ & 79.86 & 20.14 \\
\hline $\begin{array}{l}\text { 17. Presenting products, ideas or reports to } \\
\text { others }\end{array}$ & 79.57 & 20.43 \\
\hline 18. Writing the reports or documents & 80.14 & 19.86 \\
\hline \multirow[t]{2}{*}{$\begin{array}{l}\text { 19. Writing and speaking in second } \\
\text { language }\end{array}$} & 82.43 & 17.57 \\
\hline & 79.71 & 20.29 \\
\hline
\end{tabular}

All the values in the table are in percentages; Optimal Level $=100 \%$; Desire-Gap $=$ Optimal Level - Desire Level 
Table 4.1 shows desire-gap of generic competences as perceived by prospective teachers enrolled in B.Ed 4-year programme. The average desire-gap of generic competences is $20.29 \%$. Results about competence-wise desire-gap reveal that the maximum gap is $23.00 \%$ in knowledge about other disciplines and minimum gap is $16.00 \%$ in mastery on one's own discipline. The average desiregap (i.e. $20.29 \%$ ) follows that the prospective teachers do not desire to achieve the optimal level of generic competences.

Table 4.2

\section{Achievement-gap of Generic Competences}

Competences

Perceived Achievement Gap

Level

1. Mastery of one's own discipline

67.29

32.71

2. Knowledge of other disciplines

55.86

44.14

3. Think analytically

64.00

36.00

4. Rapidly acquiring new knowledge

69.14

30.86

5. Effective negotiation

62.43

37.57

6. Performing well under pressure

65.57

34.43

7. Preparedness to novel opportunities

66.86

33.14

8. Co-ordinate with others

69.29

30.71

9. Efficient use of time

68.00

32.00

10. Work productively with others

71.57

28.43

11. Mobilizing abilities of others

66.00

34.00

12. Making your meanings clear to others

72.57

27.43

13. Asserting your authority

65.00

35.00

14. Using computers and the internet

76.71

23.29

15. Coming up with the innovative ideas and

72.71

27.29 solutions

16. Preparedness to question your and others' ideas

69.86

30.14

17. Presenting products, ideas or reports to others

69.71

30.29

18. Writing the reports or documents

65.00

35.00

19. Writing and speaking in second language

61.14

38.86

Average

67.29

32.71

All the values in the table are in percentages; Optimal Level $=100 \%$; Achievement-Gap $=$ Optimal Level - Achievement Level

The values in the table 4.2 reflect the achievement-gap of generic competences as perceived by prospective teachers enrolled in B.Ed 4-year programme. The average achievement-gap of generic competences is $32.71 \%$. Results about competence-wise achievement-gap depict that the maximum gap is $44.14 \%$ in knowledge about other disciplines and minimum gap is $23.29 \%$ in using computers and internet. The achievement gap i.e. $32.71 \%$ follows that the prospective teachers do not achieve the optimal level of generic competences. 
Table 4.3

Desire-Achievement Gap in Generic Competences

\begin{tabular}{lccc}
\hline \multicolumn{1}{c}{ Competences } & $\begin{array}{c}\text { Perceived Desire } \\
\text { Level }\end{array}$ & $\begin{array}{c}\text { Perceived } \\
\text { Achievement } \\
\text { Level }\end{array}$ & Gap \\
\hline 1. Mastery of one's own discipline & 84.00 & 67.29 & 19.89 \\
2. Knowledge of other disciplines & 77.00 & 55.86 & 27.45 \\
3. Think analytically & 79.14 & 64.00 & 19.13 \\
4. Rapidly acquiring new knowledge & 80.29 & 69.14 & 13.87 \\
5. Effective negotiation & 75.00 & 62.43 & 16.76 \\
6. Performing well under pressure & 78.14 & 65.57 & 16.08 \\
7. Preparedness to novel opportunities & 80.43 & 66.86 & 16.87 \\
8. Co-ordinate with others & 77.86 & 69.29 & 11.00 \\
9. Efficient use of time & 81.00 & 68.00 & 16.04 \\
10. Work productively with others & 79.43 & 71.57 & 09.89 \\
11. Mobilizing abilities of others & 78.29 & 66.00 & 15.69 \\
12. Making your meanings clear to & 81.29 & 72.57 & 10.72 \\
others & & & \\
13. Asserting your authority & 79.14 & 65.00 & 17.87 \\
14. Using computers and the internet & 82.43 & 76.71 & 06.93 \\
15. Coming up with the innovative ideas & 81.14 & 72.71 & 10.38 \\
and solutions & & & \\
16. Preparedness to question your and & 79.86 & 69.86 & 12.52 \\
others' ideas & & & \\
17. Presenting products, ideas or & 79.57 & 69.71 & 12.38 \\
reports to others & & & \\
18. Writing the reports or documents & 80.14 & 65.00 & 18.89 \\
19. Writing and speaking in second & 82.43 & 61.14 & 25.82 \\
language & & 67.29 & 15.59 \\
\hline All & 79.71 & 100 & $\mathrm{D}$ \\
\hline
\end{tabular}

All the values in the table are in percentages; Optimal Level $=100 \%$ DesireAchievement Gap $=$ Desire Level - Achievement Level

Table 4.3 indicates the desire-achievement gap of generic competences as perceived by prospective teachers enrolled in B.Ed 4-year programme. The average desire-achievement gap is $15.59 \%$ in generic competences. Results regarding competence-wise desire-achievement gap show the maximum gap is $27.45 \%$ in knowledge about other disciplines, while minimum gap is $06.93 \%$ in using computers and internet. The desire-achievement gap (i.e. $15.59 \%$ ) follows that the desire level of prospective teachers is higher than that of the achievement level of generic competences. 
Table 4.4

Correlation between Desire and Achievement Level of Competences

\begin{tabular}{ccc}
\hline $\mathrm{N}$ & $\mathrm{r}$ & $\mathrm{P}$ \\
\hline 210 & 0.34 & 0.00 \\
\hline
\end{tabular}

Table 4.4 reveals that the Pearson correlation is applied to find the relationship between desire and achievement level of prospective teachers enrolled in B.Ed 4-year programme regarding generic competences. The values in the table depict that there is a statistically significant correlation between desire and achievement level of prospective teachers regarding generic competences. It is meant that positive relationship exists between desire and achievement level of prospective teachers regarding generic competences.

\section{Discussion}

The aim of this study was to explore the gap between the desire and achievement level of generic competences among students of Bachelor of Education 4-year programme i.e. prospective teachers. The results of the study reflected that there was a gap in the desire and achievement levels of all 19 generic competences among prospective teachers enrolled in B.Ed 4-year programme. It means that the prospective teachers could not achieve the level of competences whatever they desire from the programme. The detailed discussion on three gaps - desire-gap, achievement-gap and desire-achievement gap is provided in ensuing paragraphs.

The overall desire-gap in all 19 generic competences was observed in perception of prospective teachers enrolled in B.Ed 4-year programme. The maximum desire-gap was found in knowledge of other disciplines and minimum desire-gap was observed in mastery of one's own discipline. The gaps depicts that prospective teachers' desire level of generic competences was less than the optimal level. The results of present study are aligned with the study of Bui and Porter (2010). They found desire-gap between the desires of employers and teachers about the competences that graduates of accounting actually perform in the field. In contrast, the results of the study conducted by Low et al. (2016) regarding desire-gap were contradicted from the results of present study. In his study, the desire-gap was not found among accounting students of New Zealand. The achievement-gap was also observed in perception of prospective teachers. The maximum achievement-gap was found in knowledge of other disciplines to minimum in using computers and the internet. The prospective teachers' achieved level of generic competences was less than the optimal level of the generic competences. The desire-achievement gap was also found in perception of prospective teachers and teacher educator regarding generic competences. The 
desired level of prospective teachers regarding generic competences was greater than that of the achieved level. It means that the prospective teachers were not achieved the competences whatever they desired from the programme. The results of various studies (Hakim \& Bizri, 2015; Junior, 2014; Metilda \& Neena, 2016; Parvaiz, 2014; Shah et al., 2017; Siddoo, Sawattawee, Janchai, \& Yodmongkol, 2017a; Subramonian, 2008) were found aligned with that of the present study.

Higher achieved level of generic competence during higher education guarantees better professional performance (Shah et al. 2017). The gap in student's achievement level of generic competences throughout their career is major hindrance in their successful professional life. This is an alarming situation for student's success in career as well as productivity of the industry. Positive correlation was also observed between desire and achievement (of generic competences) level of prospective teachers. It may lead to conclude that high desire level of prospective teachers regarding generic competences may bring high achievement level.

\section{Conclusions}

The present study aimed to analyse the gap between desire-achievement levels of prospective teachers regarding generic competences. This study investigated three gaps - desire-gap, achievement-gap, and desire-achievement gap. It was concluded that all three gaps existed in desired and achievement level of prospective teachers regarding generic competences. The details of gaps are given as under.

The desire-gap of generic competences was found in perception of prospective teachers enrolled in B.Ed 4-year programme. The prospective teachers' average desire level of generic competences was $79.71 \%$; the average desire-gap was found to be $20.29 \%$ - less than the optimal level (i.e. $100 \%$ ). The maximum desire-gap was $23.00 \%$ in knowledge of other disciplines and minimum $16.00 \%$ in mastery of one's own discipline. The prospective teachers' desire level of generic competences was less than the optimal level. It means that the prospective teachers do not desire to achieve the optimal level of generic competences.

The achievement-gap was also observed in perception of prospective teachers. Average achievement-gap between achieved (67.29\%) and optimal level $(100 \%)$ was $32.71 \%$. The achievement-gap was maximum $44.14 \%$ in knowledge of other disciplines to minimum $23.29 \%$ in using computers and the internet. The prospective teachers' achieved level of generic competences was less than the optimal level of the generic competences. It means that the prospective teachers do not achieve the optimal level of generic competences. 
The desire-achievement gap of generic competences was found in perception of prospective teachers. The desired level of prospective teachers regarding generic competences was greater than that of the achieved level. The prospective teachers' average desire-achievement level of generic competences was $84.41 \%$; the average desire-achievement gap was found to be $15.59 \%$. The maximum desire-achievement gap was $27.45 \%$ in knowledge of other disciplines, while minimum gap $6.93 \%$ in using computers and the internet. Teacher educators also certified the desire-achievement gap of generic competences among prospective teachers. It means that the prospective teachers did not achieve the competences whatever they desired from the programme.

Positive correlation between desired and achievement (of generic competences) level of prospective teachers may lead to conclude that high desire level may bring high achievement level. Prospective teachers' average desireachievement gap was $15.59 \%$. Minimising this gap with bringing achievement level approaching optimal level is convincingly believed to be attained by the prospective teachers. The desire level of prospective teachers was $79.71 \%$; whereas, achievement level was $67.29 \%$. This makes it perceptible that high desire level precedes high achievement level. Those who aspire for more have greater probability of ending up with more than those who do not do.

\section{Recommendations}

1. The prospective teachers desired and achieved level of generic competences was less than the optimal level. The curriculum planners should strengthen the development of generic competences in the curricula of B.Ed 4-year programme.

2. The heads of the departments of education may sensitize, motivate and guide teacher educators about significance of generic competences and their evaluation through various assessment strategies.

3. The teacher educators need to implement innovative teaching strategies to inculcate generic competences in the students of the programme.

\section{References}

Bui, B., \& Porter, B. (2010). The expectation-performance gap in accounting education: An exploratory study. Accounting Education: an international journal, 19(1-2), 23-50.

Chan, R. Y., Brown, G. T., \& Ludlow, L. H. (2013). What is the purpose of higher education?: Comparing student and institutional perspectives for completing a bachelor's degree in the $21^{\text {st }}$ century.JEPA, 6(5), 1-41. 
Cunha, M., Aparício, G., Madureira, A., Menezes, L., Menezes, N., Nascimento, M., \& Santos, C. (2019). Generic and Specific Competencies of the Supervisor in Pedagogical Context. International Journal of Arts and Social Science, 1(2), 1-10.

De La Harpe, B., Radloff, A., \& Wyber, J. (2000). Quality and Generic (professional) Skills. Quality in Higher Education, 6(3), 231-243.

Fastré, G. M., van der Klink, M. R., Sluijsmans, D., \& van Merriënboer, J. J. (2013). Towards an integrated model for developing sustainable assessment skills. Assessment \& Evaluation in Higher Education, 38(5), 611-630.

Gibbons, M. (1994). The new production of knowledge: The dynamics of science and research in contemporary societies. Sage.

Gillies, A., \& Howard, J. (2003). Managing change in process and people: Combining a maturity model with a competency-based approach. Total Quality Management \& Business Excellence, 14(7), 779-787.

Hakim, C., \& Bizri, R. M. (2015). The education gap in the accounting profession evidence from Lebanon. World Review of Business Research, 5(3), 13-29.

Howells, K. (2018). The Future of Education and Skills: Education 2030: The Future We Want. Retrieved from https://www.oecd.org/education/2030/E2030\%20Position\%20Paper\%20( 05.04.2018).pdf

Junior, M. R. (2014). Reducing the expectation-performance gap in assurance of Global Reporting Initiative (GRI) sustainability reports in Brazil. University of Southern Queensland.

Kamphorst, J., Hofman, W., Jansen, E., \& Terlouw, C. (2013). The relationship between perceived competence and earned credits in competence-based higher education. Assessment \& Evaluation in Higher Education, 1-16.

Kwan, W. W. (2016). Identifying core competencies for students of a Vocational Education and Training (VET) Programme in electrical and mechanical engineering in Hong Kong (Doctoral Thesis).The Education University of Hong Kong. 
Longweni, M., \& Kroon, J. (2016). Managers' message sending skills and ability to deal with interference: green panacea or red herring? Journal of Contemporary Management, 13(1), 1225-1254.

Low, M., Botes, V., De La Rue, D., \& Allen, J. (2016). Accounting employers' expectations-the ideal accounting graduates. e-Journal of Business Education and Scholarship of Teaching, 10(1), 36-57

Mahmood, S. (2017). Testing the effectiveness of a critical thinking skills intervention for initial teacher education students in Pakistan. University of Southampton.

Male, S. A. (2010). Generic engineering competencies: A review and modelling approach. Education research and perspectives, 37(1), 25.

Metilda, R. M., \& Neena, P. (2016). Gap Analysis of Employability Skills of Entry Level Business Graduates Based on Job-Fit Theory. International Journal of Social Sciences and Management, 3(4), 294-299.

Mulder, M. (2007). Competence-the essence and use of the concept in ICVT. European Journal of Vocational Training, 40, 1-17.

Naidoo, J., Jackling, B., Oliver, B., \& Prokofieva, M. (2011). Identifying the employment expectation-performance gaps of early career accounting graduates (Unpublished Thesis).Victoria University.

Parvaiz, G. (2014). Skills expectation-performance gap: A study of Pakistan's accounting education (Doctoral Thesis). Brunei University.

Richta, R. (2018). Civilization at the Crossroads: Social and Human Implications of the Scientific and Technological Revolution (International Arts and Sciences Press): Social and Human Implications of the Scientific and Technological Revolution, Routledge.

Rowe, C. (1995). Clarifying the use of competence and competency models in recruitment, assessment and staff development. Industrial and Commercial Training, 27(11), 12-17.

Rodríguez, R. d. C. M., Corona, L. B., \& Espinosa, A. H. (2019). Generic Competencies for Globalization from the Perspective of Engineering Students. Bulgarian Comparative Education Society. Paper presented at 
the Annual International Conference of the Bulgarian Comparative Education Society (BCES).

Serna, A. G., Vega, J. L. A., García, J. J. S., \& Ruiz, M. A. O. (2018). Generic Competencies in the Education of Engineers: The Case of Engineering Program in a Public University in Mexico. Higher Education Studies, $8(1), 58-64$.

Shah, A. A. (2009). Contributions and limitations of self assessment of competences by higher education graduates. Universite de Bourgogne.

Shah, A. A., Sarwar, M., \& Shah, S. A. (2017). Assessing Generic Competence Development among Higher Education Students. Pakistan Journal of Education, 34(1), 1-20.

Shamim-ur-Rasul, S. (2012). Validation of a Selected List of Competences. (MPhil). Education. University of Sargodha, Sargodha.

Siddoo, V., Sawattawee, J., Janchai, W., \& Yodmongkol, P. (2017a). Exploring the Competency Gap of IT Students in Thailand: The Employers 'view of an Effective Workforce. Journal of Technical Education and Training, 9(2).

Siddoo, V., Sawattawee, J., Janchai, W., \& Yodmongkol, P. (2017b). Exploring the competency gap of IT students in thailand: the employers'view of an effective workforce. Journal of Technical Education and Training, 9(2).

Sidhu, M. S., \& Pascual, P. A. C. (2010). Educational Technoethics Applied to Career Guidance: Technology-Assisted Problem Solving for Engineering Education (pp. 175-188): IGI Global.

Subramonian, H. (2008). Competencies gap between education and employability stakes. TEAM Journal of Hospitality \& Tourism, 5(1), 4560 .

Teixeira, P., Teixeira, P. N., Cardoso, S., Rosa, M. J., \& Magalhães, A. (2016). Graduates' Perceptions about Labour Market Competencies: Does the Type of Institution and Programme Make a Difference? Higher Education Policy, 29(1), 109-129. 
Tuononen, T. M. (2019). Employability of university graduates: The role of academic competences, learning and work experience in the successful transition from university to working life (Doctoral Thesis). University of Helsinki.

Young, J., \& Chapman, E. (2010). Generic competency frameworks: A brief historical overview. Education Research and Perspectives, 37(1), 1-24.

\section{Citation of this Article:}

Jabeen, M., Sarwar, M., \& Shah, A. A. (2020). Exploring the Gap Analysis of Generic Competencies of Pre-Service Teachers in Pakistan. International Journal of Innovation in Teaching and Learning (IJITL), 6(1), 35-50. 